\title{
An Experimental Inoculation System to Study Citrus-Xylella fastidiosa Interactions
}

\author{
S. A. Lopes, D. C. Teixeira, N. G. Fernandes, and A. J. Ayres, FUNDECITRUS, Araraquara, SP, Brazil, 14801- \\ 970; S. C. Z. Torres, UNAERP, Ribeirão Preto, SP, 14096-380; J. C. Barbosa, UNESP, Jaboticabal, SP, 14884-900; \\ and W. B. Li, USDA-ARS, Beltsville, MD 20705-2350
}

\begin{abstract}
Lopes, S. A., Teixeira, D. C., Fernandes, N. G., Ayres, A. J., Torres, S. C. Z., Barbosa, J. C., and Li, W. B. 2005. An experimental inoculation system to study citrus-Xylella fastidiosa interactions. Plant Dis. 89:250-254.

Difficulties in reproducing the citrus variegated chlorosis (CVC) disease symptoms in experimental plants have delayed implementation of studies to better understand the essential aspects of this important disease. In an extensive study, cultivars of sweet orange (Citrus sinensis) were inoculated with Xylella fastidiosa using procedures that included root immersion, and stem absorption, pricking, or infiltration of the inoculum into plants of different ages. Inoculum consisted of 5-day-old cultures or cell suspensions of CVC strain 9a5c diluted in phosphate-buffered saline. Inoculated plants and controls were grown, or transferred just after inoculation, to 5-liter pots or 72-cell foam trays. Approximately 4, 5, 9, and 12 months after inoculation, leaves were collected and processed for polymerase chain reaction analysis or $X$. fastidiosa isolation on BCYE agar medium. Root immersion and stem inoculation of 4- and 6-month-old plants resulted in low percentages of symptomatic (0 to $7 \%)$ and plants positive by isolation (0 to $9 \%)$. Pinpricked or injected stems of 1-month-old seedlings resulted in high percentages of plants symptomatic (29 and $90 \%$ in Pera Rio, 75, 59, and 83\% in Valencia, and 77\% in Natal) or positive by isolation (26 and 93\% in Pera Rio, 98, 96, and 83\% in Valencia, and $77 \%$ in Natal). In foam trays, the seedlings grew less, the incubation period was shorter, and disease severity was higher than in pots. This system allows testing of higher numbers of plants in a reduced space with a more precise reproduction of the experimental conditions.
\end{abstract}

Citrus variegated chlorosis (CVC), caused by the xylem-limited bacterium Xylella fastidiosa, was first described in 1987 and is one of the main citrus diseases in Brazil. Application of insecticides for reduction of vector populations, pruning and eradication of symptomatic trees for reduction of inoculum sources, and use of healthy stock material for planting are management practices that have been recommended to growers for years (3). In the last few years, CVC incidence has remained above $35 \%$, and in 2003 it reached $43 \%$ of the estimated 200 million trees growing in the main citrus regions of the states of São Paulo and Minas Gerais (see the Fundecitrus website). The persistence of high disease incidence is an indication that controls are not totally effective.

The procedures used to control CVC were developed empirically (12) based on information that the bacterium is limited to the plant vascular system and is transmitted among citrus trees by leafhoppers. Clearly, there is a need for more informa-

Corresponding author: S. A. Lopes

E-mail: slopes@fundecitrus.com.br

Accepted for publication 29 September 2004.

DOI: 10.1094/PD-89-0250

(C) 2005 The American Phytopathological Society tion on this pathosystem, for example, on how CVC is affected by the environment, on the pathological homogeneity of the population of this pathogen that affects several citrus cultivars grown in a large geographic area, and the basis for resistance of limes, lemons, and tangerines to the disease (6). Elucidation of these aspects of CVC is essential for improvement or development of new practices leading to more effective disease management and reduction in disease incidence.

Difficulties in reproducing CVC symptoms under experimental conditions using cultured $X$. fastidiosa bacterial cells as inoculum has been the main obstacle for the acquisition of more detailed information on CVC. This situation led some to use grafting methods to study bacterial transmission and citrus resistance to CVC. In one study, healthy buds were grafted onto diseased trees and the disease was evaluated on the newly developed shoots (10), and in other studies pieces of branches, removed from diseased trees, were grafted to the stems of healthy citrus plants $(4,7,15)$. Low levels of bud survival, heterogeneous growth of the grafted shoots, low frequency of infection, delays in symptom appearance, symptom remission, and the lack of reproducibility of experimental data between laboratories or between field observations and experimental data were major problems $(4,10,15)$.
Scion-rootstock incompatibility and the poor condition of the diseased tissues used for grafting could be the reasons for low scion survival $(4,10)$, and variation in the amount and viability of the bacterial cells present in inoculum sources could be the reason for different results. Recently, the pinprick method was used to study $X$. fas tidiosa multiplication and movement in citrus seedlings (1). High infection rates were obtained by probing the stem of 15to 20 -cm-tall citrus seedlings with $2 \mu \mathrm{l}$ of cell suspension, and CVC leaf symptoms were first observed 2 months after inoculation.

The objective of this work was to develop an inoculation system that would facilitate studies of citrus- $X$. fastidiosa interactions. Six methods of inoculation were compared using several hundred young seedlings and mature citrus plants. Partial results of this work have been presented (9)

\section{MATERIALS AND METHODS}

From December 2001 to January 2004, several experiments were initiated in greenhouses located at Fundecitrus, Araraquara, SP (greenhouse 1) and at the Department of Biotechnology, University of Ribeirão Preto (UNAERP), Ribeirão Preto, SP (greenhouse 2). These greenhouses are outfitted with similar cooling pad systems to avoid the high temperatures during the summer season. In greenhouse 1, temperature was recorded with a HOBO data logger (Onset Computer Corporation, Bourne, MA) programmed to record the temperature every hour. In greenhouse 2, temperature was determined using a maximum/minimum mercury thermometer. The minimum and maximum weekly averages ranged from 13 to $38^{\circ} \mathrm{C}$ inside greenhouse 1 and from 13 to $36^{\circ} \mathrm{C}$ inside greenhouse 2 .

Inoculum preparation. Strain $9 \mathrm{a} 5 \mathrm{c}$ of $X$. fastidiosa (14) was recovered in periwinkle wilt (PW) agar (2) from glycerol culture stocks maintained at $-70^{\circ} \mathrm{C}$. The colonies recovered were transferred to liquid PW medium (2) and grown for 5 days at $28^{\circ} \mathrm{C}$. PW cultures were used directly as inoculum (sterile medium as controls) in two experiments involving trunk inoculation and pinprick at seedling stems (see methods 1 and 5 below). In the remaining experiments, the inoculum consisted of a phosphate-buffered saline (PBS) 
suspension of $X$. fastidiosa cells that were recovered from 5-day-old PW cultures by centrifugation. Serial dilution of the original suspension or culture and plating of $50-\mu$ l aliquots on PW agar allowed an estimation of the number of colony-forming units (CFU) per milliliter of inoculum.

Experimental evaluations. Inoculated plants and controls were observed for the presence of leaf symptoms consisting of leaf variegated chlorosis (13). The number of symptomatic plants was counted at 4,5 , 9 , or 12 months postinoculation, and samples were processed for pathogen detection by PCR (11) or culturing in BCYE agar medium (16).

Detection of $X$. fastidiosa by culturing. Petioles and midribs of three leaves, detached above or between inoculation sites, were surface-sterilized in $70 \%$ ethanol for $1 \mathrm{~min}, 1 \%$ sodium hypochlorite for $3 \mathrm{~min}$, and washed twice in sterile water. The samples were cut into $0.5-\mathrm{cm}$ sections and macerated in $1 \mathrm{ml}$ of sterile PBS. The macerated samples were diluted 100- and 1,000-fold and plated using $20 \mu \mathrm{l}$ of each dilution on the surface of BCYE agar medium (16). The plates were inclined to distribute the liquid on the agar surface and incubated for at least 30 days at $28^{\circ} \mathrm{C}$.

PCR detection of $X$. fastidiosa. Samples for PCR analysis consisted of three leaves detached above or between inoculation sites, depending on the method of inoculation. The base of the petiole was inserted tightly into a small plastic tube that was attached to a $20-\mathrm{ml}$ syringe containing Milli $\mathrm{Q}$ water filtered through a $0.2-\mu \mathrm{m}$ membrane. The water was forced through the petioles and midribs, and the xylem extracts were collected in $1.5-\mathrm{ml}$ Eppendorf tubes at the midrib extremity. The collected extracts were centrifuged at $15,300 \times g$ for $10 \mathrm{~min}$ in a Eppendorf 5417R microcentrifuge (Brinkmann Instruments, Westbury, NY) and the supernatants discarded. The tubes were centrifuged again at $330 \times g$ for $5 \mathrm{~min}$ in a lowspeed vacuum centrifuge (DNA mini; Heto-Holten, Allerod, Denmark) for sample drying. Twenty microliters of filtered water was added to each tube, and the tubes were vortexed for $5 \mathrm{~s}$. Ten microliters of each sample was added to $10 \mu \mathrm{l}$ of solution of the PCR master mix containing the reaction buffer $(20 \mathrm{mM}$ Tris- $\mathrm{HCl}, \mathrm{pH}$ 8.4, $\left.50 \mathrm{mM} \mathrm{KCl}, 2.5 \mathrm{mM} \mathrm{MgCl}_{2}\right), 0.2 \mathrm{mM}$ of dNTP, $500 \mathrm{nM}$ of primers 272-1 and 272-2 (11), and 0.2 U of Taq DNA polymerase (Gibco-BRL, Gaithersburg, MD). PCR was run for 34 cycles of $94^{\circ} \mathrm{C}$ for 1 min, $64^{\circ} \mathrm{C}$ for $1 \mathrm{~min}$, and $72^{\circ} \mathrm{C}$ for $1.5 \mathrm{~min}$. The entire reacted volume was applied to $1 \%$ agarose gel and electrophoresed for 60 $\min$ at $3 \mathrm{~V} / \mathrm{cm}$. The gels were photographed with a Polaroid Fotodyne camera (Fotodyne, Hartland, WI) over a UV transilluminator. Bands of approximately 500 bp (identical in size to that obtained for the positive control $[X$. fastidiosa cell suspen- sion]) were counted on gel photographic images for diagnostic purposes.

Inoculation method 1: trunk slicing and pricking. Six-month-old Pera Rio sweet orange seedlings were inoculated. Approximately the middle portion of each stem $(1.0 \mathrm{~cm}$ diameter) was sliced with a pocket knife half of the stem diameter. Immediately after cutting, $100 \mu \mathrm{l}$ of the PW culture of strain 9a5c, containing $4 \times$ $10^{8} \mathrm{CFU} / \mathrm{ml}$, was deposited on the exposed vascular system, which was stabbed five times with a $25 \times 7$ hypodermic needle. The sliced tissue was replaced in its original position, and the inoculated site was tightly wrapped with a piece of Parafilm. Controls were inoculated with sterile PW medium. One hundred and fifty inoculated test plants and 52 control plants were prepared on 19 December 2001 and were maintained inside greenhouse 1 .

Inoculation method 2: passive inoculum absorption into the trunk. The middle portions of the stems of 20 6-monthold sweet orange plants (cv. Caipira) of 1.0 $\mathrm{cm}$ diameter were perforated with a highspeed electric drill (Dremel, Racine, WI) to make a hole of $2 \mathrm{~mm}$ diameter. The stems were perforated up to half of their diameter $(1 \mathrm{~cm})$, at angles of more or less 45 degrees from the vertical. A 1-ml pipetman tip containing $1 \mathrm{ml}$ of a $X$. fastidiosa cell suspension $\left(10^{9} \mathrm{CFU} / \mathrm{ml}\right)$ or just PBS was firmly inserted into each stem and maintained in the holes for $3 \mathrm{~h}$. To facilitate inoculum absorption, half of the leaves above the inoculation site were transversally cut and removed. The volume of absorbed liquid was measured after $3 \mathrm{~h}$. The experiment began on 1 April 2002 and was maintained inside greenhouse 1 for 1 year.

Inoculation method 3: trunk infiltration. The middle portions of the stems of 90 plants of 6-month-old Caipira sweet orange seedlings were transversally perforated up to half of the stem diameter, as described. The basal portion of a $20 \times 20$ needle, attached to a syringe commonly used in chicken vaccination (Höppner, São Paulo, SP, Brazil), was placed in the drilled hole. The inoculum (PBS suspension containing $10^{8} \mathrm{CFU}$ of $X$. fastidiosa per $\mathrm{ml}$ ) or just PBS (control) was then infiltrated into the stems until it appeared at the surface of a cross section made $10 \mathrm{~cm}$ above the inoculation site. Bromphenol blue was infiltrated into the stems of four plants in order to estimate the amount of inoculum that was injected. The plants were inoculated on 22 April 2002 and maintained inside greenhouse 1 for 1 year.

Inoculation method 4: root immersion. Forty-two 4-month-old cv. Caipira sweet orange seedlings and 55 6-monthold cv. Valencia sweet orange plants were removed from their potting media (Plantmax Citrus; Eucatex, Paulinia, SP, Brazil) and washed thoroughly with tap water. The root systems of 30 Caipira and 40 Valencia plants were submerged for $3 \mathrm{~h}$ in a PBS suspension containing $10^{9} \mathrm{CFU}$ of $X$. fastidiosa per $\mathrm{ml}$. The remaining plants were submerged in PBS. The plants were transplanted to 5-liter pots containing sandy soil (red Latosol) and maintained in greenhouse 1 . The experiment was initiated on 1 April 2002. In order to assess the extent of inoculum uptake by the roots, three plants of each cultivar were placed in a $0.25 \%$ solution of bromphenol blue for $3 \mathrm{~h}$. The root systems were washed, and cross sections of the root extremities were observed to determine the approximate distance of dye movement from the roots.

Inoculation method 5: pinprick stem inoculation. Seeds of Pera Rio and Valencia sweet orange were removed from fruits collected from asymptomatic trees of a grove free of CVC in Casa Branca County, $\mathrm{SP}$, where CVC incidence is very low. Peeled seeds were sown in 10-liter pots containing the potting mix Plantmax Citrus and were maintained in greenhouse 1 . The seeds germinated, and 1 month later the seedlings were approximately $5 \mathrm{~cm}$ in height. Uniform seedlings were carefully removed from the pots. Inoculum, consisting of liquid PW culture containing $10^{9}$ CFU of $X$. fastidiosa per $\mathrm{ml}$, was placed at three sites on the stems ( $3 \mu$ at each site) with a pipetman, and each site was perforated five times with an insulin needle. The seedlings were maintained in a horizontal position for 5 to $10 \mathrm{~min}$ for inoculum absorption. Control plants were inoculated with sterile PBS. After inoculation, the seedlings were transplanted to 5-liter pots containing a mixture of sandy soil and cow manure in the bottom two-thirds, and Plantmax Citrus in the upper one-third. Tested plants were maintained inside greenhouse 1. Valencia (150 inoculated and 50 controls) and Pera Rio (148 inoculated and 50 controls) seedlings were inoculated on 24 December 2001 and 10 January 2002, respectively.

Inoculation method 6: inoculum injection of seedling stems. This method was tested in two experiments, on 24 July 2002 (first experiment including just Valencia) and on 15 April 2003 (second experiment including Valencia, Pera Rio, and Natal sweet orange cultivars). The inoculum consisted of PBS suspensions of $X$. fastidiosa cells recovered by centrifugation of 5-day-old PW liquid cultures. Instead of pinpricking, the inoculum (containing $6 \times$ $10^{9}$ and $5 \times 10^{9} \mathrm{CFU} / \mathrm{ml}$ ) was injected with a syringe and insulin needle at two sites (after the first and second upper third portions) on the stems of 1-month-old seedlings. The soil-Plantmax substrate combination was changed to Plantmax Citrus plus the slow-release fertilizer Osmocote at $10 \mathrm{~g} /$ liter (Scotts Company, Maryville, $\mathrm{OH})$ at the formulation $14 \mathrm{~N}: 14 \mathrm{P}: 14 \mathrm{~K}$. In order to reduce space, the 5-liter pots were replaced by foam trays of 72 pyramidal cells of $100 \mathrm{ml}$ each. In the first ex- 
periment, one tray with 30 inoculated seedlings and 6 controls plus 6 inoculated potted seedlings (containing the same substrate used in the pinprick inoculation method) were maintained in greenhouse 1 and greenhouse 2 .

\section{RESULTS}

A summary of the inoculation methods and the results obtained is shown in Table 1. Leaf symptoms were not observed and the pathogen was not detected in any of the control plants.

The wounds made during the inoculation process (method 1) did not cause visible plant stress and were completely healed 1 month after inoculation. Leaf symptoms typical of CVC were first detected 6 months after inoculation in 8 of $150(5.3 \%) X$. fastidiosa-inoculated plants. Six months later, three additional plants were symptomatic. However, the leaf chlorosis seen in the previous 8 plants was not evident. The pathogen was isolated from all symptom expressing plants and from three asymptomatic ones (Table 1). $X$. fastidiosa was detected by PCR from 21 (14\%) and $27(18 \%)$ plants at 6 and 10 months after inoculation.

In experiments with passive stem absorption of $X$. fastidiosa cell suspension (method 2), $3 \mathrm{~h}$ after inoculum deposition, the total 1-ml volume was absorbed by 6 of 15 plants. Only one plant did not absorb any inoculum, and the other eight plants absorbed 0.33 to $0.90 \mathrm{ml}$. Despite the high amount of $X$. fastidiosa cells absorbed by most plants $\left(0.3\right.$ to $\left.1.0 \times 10^{9} \mathrm{CFU}\right)$, the new shoots that developed above the inoculation site did not manifest any CVC leaf symptoms and did not test positive by PCR or pathogen isolation 9 and 12 months after inoculation.

The exact amount of inoculum infiltrated into the stems (method 3) was not measured, but the amount of blue dye solution observed where the upper stem portion was removed indicated that at least $100 \mu \mathrm{l}$ was infiltrated into each plant. Despite the severity of this inoculation process, and the relatively high volume of inoculum placed into the vascular system, none of the several new shoots that developed on the 60 inoculated plants tested positive by pathogen isolation 7 months after inoculation or showed any CVC symptoms during the 12-month observation period.

Immersion of the root system of 4- or 6month-old citrus in a PBS suspension of $X$. fastidiosa cells (method 4) also resulted in low infection frequencies. The pathogen was detected by PCR in two Caipira (7\%) and in three Valencia (8\%) plants at 8 months, and by culturing in two Caipira and one Valencia plants at 1 year after inoculation. Leaf symptoms were observed in one Valencia plant 8 months after inoculation. Visual observation of serial cross sections of the roots immersed in bromphenol indicated that the blue dye penetrated no more than $1 \mathrm{~cm}$ in from the root tips.

Considerably higher infection frequencies were obtained when the stems of 1month-old seedlings were pinprick inoculated (method 5). Three months after inoculation, a few inoculated plants of both cultivars showed distinct leaf abnormalities when compared with controls. The angle of attachment of the basal leaves to the stem was visibly reduced. Around 1 month later, a pale yellowing was observed in one or few sites of some leaves of these plants. Five months after inoculation, chlorotic leaves and leaves with typical CVC symptoms were collected from 40 plants, photographed, and processed for pathogen isolation on BCYE agar plates. X. fastidiosa was isolated in high populations from all samples, regardless of the intensity of the chlorosis. The number of $X$. fastidiosa colonies was so large (even from leaf macerate diluted 1,000-fold) that they could not be accurately counted, and therefore, no correlation was made between cell population and symptom intensity. Plants showed symptoms more quickly in Valencia than in Pera Rio. The percentages of plants showing symptoms were $9,45,56$, 75 , and $85 \%$ in Valencia and $1,6,17,29$, and $46 \%$ in Pera Rio at 4, 5, 9, 12, and 18 months after inoculation, respectively. However, PCR of the eluted sap indicated that the levels of infection of both cultivars were almost identical, with $96 \%$ in Valencia and $95 \%$ in Pera Rio, 9 months after inoculation. Samples were collected from all inoculated plants and controls, and attempts were made to isolate the pathogen on agar plates, as described. $X$. fastidiosa was isolated from 147 (98\%) of the Valencia and $38(26 \%)$ of the Pera Rio plants 1 year after inoculation. In the Pera Rio plants, PCR was positive from 76 samples $(51 \%)$ that did not test positive by isolation or expressed CVC symptoms during the 18-month observation period.

In method 6 experiments, stems were injected with $X$ fastidiosa cell suspensions prepared in PBS, and the young seedlings were transplanted to individual compartments of 72-cell foam trays or to 5-liter pots. The inoculated seedlings grown on foam trays manifested CVC symptoms earlier and in higher frequencies than inoculated seedlings grown in pots (Table 2). Alteration in the angle of leaf attachment to the stems was not observed on symptomatic tray seedlings. In greenhouse 1 , on plants grown in trays, the percentage of symptomatic plants and plants that tested positive by isolation increased from 27 and $30 \%$ at 5 months to 33 and $97 \%$ at 8 months after inoculation. The potted plants

Table 1. Summary of pathogenicity tests of Xylella fastidiosa in citrus using distinct methods of inoculation

\begin{tabular}{|c|c|c|c|c|c|}
\hline Inoculation methods & $\begin{array}{l}\text { Citrus } \\
\text { cultivars }\end{array}$ & $\begin{array}{c}\text { Inoculated } \\
\text { plants/controls }\end{array}$ & $\mathbf{P C R}^{\mathbf{b}}$ & Symptoms $^{b}$ & $\begin{array}{l}\text { Pathogen } \\
\text { isolation }\end{array}$ \\
\hline $\begin{array}{l}\text { Method } 1 \text {. Slicing and pricking of exposed stem xylem } \\
\text { of 6-month-old potted plants }\end{array}$ & Pera Rio & $150 / 52$ & $27(18)$ & $11(7)$ & $14(9)$ \\
\hline $\begin{array}{l}\text { Method 2. Stem absorption of inoculum of 6-month-old } \\
\text { potted plants }\end{array}$ & Caipira & $15 / 5$ & 0 & 0 & 0 \\
\hline $\begin{array}{l}\text { Method 3. Infiltration of inoculum into stems of } \\
\text { 6-month-old potted plants }\end{array}$ & Caipira & $60 / 30$ & - & 0 & 0 \\
\hline \multirow{2}{*}{$\begin{array}{l}\text { Method 4. Immersion of the root system of 4- (Caipira) } \\
\text { or 6-month-old (Valencia) plants into the inoculum } \\
\text { and transplanting to 5-liter pots }\end{array}$} & Caipira & $30 / 12$ & $2(7)$ & 0 & $2(7)$ \\
\hline & Valencia & $40 / 15$ & $3(8)$ & $1(3)$ & $1(3)$ \\
\hline \multirow{2}{*}{$\begin{array}{l}\text { Method 5. Pinpricking of 30-day-old seedling stems and } \\
\text { transplanting to 5-liter pots }\end{array}$} & Valencia & $150 / 50$ & $144(96)$ & $112(75)$ & $147(98)$ \\
\hline & Pera Rio & $148 / 50$ & 141 (95) & $43(29)$ & $38(26)$ \\
\hline \multirow{4}{*}{$\begin{array}{l}\text { Method 6. Inoculum injection of 30-day-old seedling } \\
\text { stems and transplanting to } 72 \text {-cell foam trays }\end{array}$} & Valencia & $54 / 12$ & - & $32(59)$ & $52(96)$ \\
\hline & Valencia & $30 / 6$ & - & $25(83)$ & $25(83)$ \\
\hline & Pera Rio & $30 / 6$ & - & $29(97)$ & $28(93)$ \\
\hline & Natal & $30 / 6$ & - & $23(77)$ & $23(77)$ \\
\hline
\end{tabular}

a Total numbers of inoculated plants that survived to the end of the experiment.

${ }^{\mathrm{b}}$ Cumulative number and percentage of inoculated plants that were positive by polymerase chain reaction (PCR), showed leaf variegated chlorosis, or tested positive by isolation on BCYE agar plates, respectively. 
did not express leaf symptoms or test positive by isolation at 5 months postinoculation, and at 8 months, only one of six (17\%) showed leaf symptoms. The pathogen was isolated on BCYE medium from this plant and from an additional asymptomatic plant. In greenhouse 2, the percentage of symptomatic plants grown in trays increased from $75 \%$ at 5 months to $92 \%$ at 8 months postinoculation. During the same period, the percentage of symptomatic plants grown in pots increased from 17 to $33 \%$. With greenhouse 2 plants, attempts to isolate the pathogen were made only at 8 months postinoculation, and they resulted in 96 and $50 \%$ of positive isolations on tray and potted plants, respectively.

Another experiment was established on 15 April 2003 using trays and included Valencia, Pera Rio, and Natal cultivars. The disease symptoms appeared sooner in Pera than in Natal or Valencia. The percentages of inoculated plants manifesting symptoms at $6,8,10$, and 12 months after inoculation were, respectively, 20, 37, 73, and $83 \%$ for Valencia, $67,73,83$, and $97 \%$ for Pera Rio, and 23, 27, 63, and 77\% for Natal. As observed in the previous experiment, culturing allowed positive identification of infected plants earlier than symptom expression. Seven months after inoculation, $X$. fastidiosa was successfully recovered from 83, 93, and $77 \%$ of the inoculated Valencia, Pera Rio, and Natal plants (Table 1).

\section{DISCUSSION}

During the last 2 years, several experiments were conducted in two greenhouses to evaluate the efficiency of various methods for the inoculation of $X$. fastidiosa into citrus plants. The high percentages of plants that tested positive by pathogen isolation and expressed leaf symptoms confirmed the virulence status of strain 9a5c of $X$. fastidiosa (8) and the appropriateness of the environmental conditions of the greenhouses. The lack of symptom development in most of the inoculated plants may be attributed to deficiencies in the various methods under investigation.

The plants used in these experiments were susceptible cultivars and could be divided into two age categories, 4- to 6month-old plants and 1-month-old seedlings. Except for the plants tested with method 4 (root inoculation), all others were tested with stem inoculations using inoculum of 5-day-old cultures of X. fastidiosa or PBS-bacterial suspensions prepared after separation of the cultured bacterial cells by centrifugation. Although precise comparison among all methods was not possible, since the plants were not inoculated on the same date, in the same location, or using the same inoculum preparation, an overall assessment of the infection percentage indicates that young seedling inoculations are better. Higher infection rates were obtained by either injecting or pricking the inoculum into the stems of young seedlings, confirming previous work (1). In our study, the first leaf symptoms were observed 4 months after inoculation against 2 months in the work of Almeida et al. (1). The longer incubation period might have resulted from the use of a distinct strain of $X$. fastidiosa for inoculation and from variations in the environmental conditions where the experiments were conducted.

Less time was required for symptom expression and higher infection rates were obtained in seedlings grown in foam trays than on potted plants $\left(\left[\chi^{2}=6.62, P<0.05\right]\right.$ for symptom expression and $\left[\chi^{2}=24.88, P\right.$ $<0.01]$ for pathogen isolation). Although not quantified, this might be due to a higher rate of $X$. fastidiosa multiplication in the stressed seedlings growing in trays. In trays, plant growth was visibly influenced by the lower amounts of potting mix and root space available. Variations in the plant nutritional status could be another reason. Plants grown in trays showed general leaf chlorosis that was corrected by urea fertilizations. Urea applications did not cause CVC symptom remission and helped symptom visualization by enhancing the contrast between the chlorotic and the normal green areas of symptomatic leaves.

In this work, the reliability of the inoculation methods investigated was assessed through the percentage of plants that expressed leaf symptoms and tested positive by pathogen isolation or by PCR. Overall, the inoculated plants that developed leaf symptoms, regardless of the inoculation method, also tested positive by isolation and PCR. Conversely, PCR allowed pathogen detection from several plants that did not test positive by isolation or develop symptoms. For example, most pinpricked plants of the cultivar Pera Rio inoculated on 10 January 2002 were positive by PCR but did not develop CVC symptoms 18 months after inoculation.

Despite considerable work with the CVC problem since the disease was first described in 1987 (13), and more recently the description of the complete genome sequence of its causal agent (14), the disease continues to cause severe losses in Brazil. Based on data of field surveys conducted year after year by Fundecitrus, it is estimated that more than 80 million trees growing in the main citrus regions are currently infected and show leaf symptoms. Lack of a good experimental method allowing detailed investigations of $X$. fastidiosa-citrus interactions has been a factor that has delayed acquisition of basic information on this pathosystem. Ultimately, this information could lead to the development of more efficient methods to control CVC and to reduce the high disease incidence in the field. Inoculation methods based on grafting have been tried but with inconsistent results. Use of leafhopper vectors is not appropriate due to the low efficiency of these insects in transmitting the pathogen (5). The method presented here based on seedling inoculations should open new opportunities for basic and applied studies to understand the mechanisms of host resistance, pathogen virulence, and the effect of environmental factors on disease development. The system involving inoculating and growing citrus seedlings in foam trays containing commercially available potting mix allows the testing of high numbers of plants in a reduced space, with good environmental control and good reproduction of the experimental conditions.

\section{ACKNOWLEDGMENTS}

This work was financed by Fundação de Amparo à Pesquisa do Estado de São Paulo (FAPESP), Grant no. 99/04345-3.

Table 2. Plants injected with a phosphate-buffered saline suspension of Xylella fastidiosa and symptomatic or positive by isolation ${ }^{\mathrm{a}}$

\begin{tabular}{|c|c|c|c|c|c|}
\hline \multirow[b]{2}{*}{ Local } & \multirow[b]{2}{*}{ Incubation period } & \multicolumn{2}{|c|}{ Leaf symptoms ${ }^{b}$} & \multicolumn{2}{|c|}{ Isolation positive ${ }^{c}$} \\
\hline & & Seedlings in trays & Seedlings in pots & Seedlings in trays & Seedlings in pots \\
\hline Greenhouse 1 & 5 & $8 / 30(27)$ & $0 / 6$ & 9/30 (30) & $0 / 6$ \\
\hline Greenhouse 1 & 8 & $10 / 30(33)$ & $1 / 6(17)$ & $29 / 30(97)$ & $2 / 6(33)$ \\
\hline Greenhouse 2 & 5 & $18 / 24(75)$ & $1 / 6(17)$ & - & - \\
\hline Greenhouse 2 & 8 & $22 / 24(92)$ & $2 / 6(33)$ & $23 / 24(96)$ & $3 / 6(50)$ \\
\hline Total & 8 & $32 / 54(59)$ & $3 / 12(25)$ & $52 / 54(96)$ & $5 / 12(42)$ \\
\hline$\chi^{2}$ & & \multicolumn{2}{|c|}{$4.62(P<0.05)$} & \multicolumn{2}{|c|}{$24.88(P<0.01)$} \\
\hline
\end{tabular}

${ }^{a}$ Inoculated seedlings were transplanted to individual cells of foam trays containing Plantmax Citrus plus Osmocote, or to 5-liter pots containing a soil and cow manure in the bottom two-thirds and Plantmax in the upper one-third.

${ }^{\mathrm{b}}$ Cumulative proportions and percentages of plants showing typical citrus variegated chlorosis (CVC) symptoms over the total number of surviving plants.

${ }^{\mathrm{c}}$ Plants that tested positive by culture on BCYE agar plates over the total number of surviving plants. 


\section{LITERATURE CITED}

1. Almeida, R. P. P., Pereira, E. F., Purcell, A. H., and Lopes, J. R. S. 2001. Multiplication and movement of a citrus strain of Xylella fastidiosa within sweet orange. Plant Dis. 85:382386.

2. Davis, M. J., French, W. J., and Schaad, N. W. 1981. Axenic culture of the bacteria associated with phony disease of peach and plum leaf scald. Curr. Microbiol. 6:309-314

3. Fundecitrus. 1997. Manual de convivência com a CVC. Ed. Fundo de Defesa da Citricultura, Araraquara SP.

4. Jaimes, E. P. G., Souza, P. S., Wickert, E., and Donadio, L. C. 2002. Avaliação da resistência à Xylella fastidiosa em germoplasma de tangerina e híbridos introduzidos da Itália e Córsega. Rev. Bras. Frutic. 24:579-582.

5. Krügner, R., Lopes, M. T. V. C., Santos, J. S., Beretta, M. J. G., and Lopes, J. R. S. 1998. Transmission efficiency of Xylella fastidiosa by sharpshooters and identification of two new vector species. (Abstr.) Page 423 in: Proc. Conf. Int. Organ. Citrus Virol. 14th. R. K. Yokomi, J. V. da Graça, and R. F. Lee, eds. IOCV, Riverside, CA.

6. Laranjeira, F. F., Pompeu, J., Jr., Harakava, R.,
Figueiredo, J. O., Carvalho, S. A., and Coletta Filho, H. D. 1998. Cultivares e espécies cítricas hospedeiras de Xylella fastidiosa em condições de campo. Fitopatol. Bras. 23:147154.

7. Li, W. B., Donadio, L. C., He, C., and Sempionato, O. R. 1996. Método de avaliação de resistência à clorose variegada dos citros. Laranja 17:55-66.

8. Li, W. B., Zreik, N. G., Fernandes, N. G., Miranda, V. S., Teixeira, D. C., Ayres, A. J., Garnier, M., and Bové, J. M. 1999. A triply cloned strain of Xylella fastidiosa multiplies and induces symptoms of citrus variegated chlorosis in sweet orange. Curr. Microbiol. 39:106-108.

9. Lopes, S. A., Teixeira, D. C., Pereira, E. O., Torres, S. C. Z., Fernandes, N. G., and Li, W. 2003. Progressos no desenvolvimento de método de inoculação de Xylella fastidiosa em plantas cítricas. (Abstr.) Fitopatol. Bras. 28:286

10. Machado, M. A., Silvério, J. L., Baptista, C. R., Cristófani, M., and Teófilo Sobrinho, J. 1992. Avaliação de transmissão e seleção de variedades à clorose variegada dos citros (CVC). Laranja 13:515-531.
11. Pooler, M. R., and Hartung, J. S. 1995. Specific PCR detection and identification of $X y$ lella fastidiosa strains causing citrus variegated chlorosis. Curr. Microbiol. 31:377-381.

12. Rodas, V. Z. 1994. Convivência com a clorose variegada dos citros. Laranja 15:129-133.

13. Rossetti, V., Garnier, M., Bové, J. M., Beretta M. J. G., Teixeira, A. R. R., Quaggio, J. A., and De Negri, J. D. 1990. Présence de bactéries dans le xylème d'orangers atteints de chlorose variégée, une nouvelle maladie des agrumes au Brésil. C. R. Acad. Sci. 310:345-349.

14. Simpson, A. J., Reinach, F. C., Arruda, P., Abreu, F. A., Acencio, M., Alvarenga, R., Alves, L. M. C., Araya, J. E., Baia, G. S., Baptista, C. S., et al. 2000. The genome sequence of the plant pathogen Xylella fastidiosa. Nature 406(6792): 151-157.

15. Souza, P. S., Donadio, L. C., and Jaimes, E. P. G. 2000. Avaliação de alguns genótipos de citros em relação à clorose variegada dos citros (CVC). Rev. Bras. Frutic. 22:148-152.

16. Wells, J. M., Raju, B. C., Nyland, G., and Lowe, S. K. 1981. Medium for isolation and growth of bacteria associated with plum leaf scald and phony peach diseases. Appl. Environ. Microbiol. 42:357-363. 